\title{
PELAKSANAAN PENILAIAN AUTENTIK DALAM PEMBELAJARAN BAHASA INDONESIA KAJIAN: ONTOLOGI, EPISTEMOLOGI, DAN AKSIOLOGI
}

\author{
Prameswari Dyah Gayatri B.A.I. \\ Program Studi Pendidikan Bahasa dan Sastra Indonesia \\ Universitas Negeri Yogyakarta \\ Dyahgayatri644@gmail.com
}

\begin{abstract}
ABSTRAK
Tujuan penelitian analisis ini untuk mendeskripsikan: (1) tinjauan ontologi penilaian autentik guru bahasa Indonesia dalam pembelajaran bahasa Indonesia; (2) tinjauan epistimologi penilaian autentik guru bahasa Indonesia dalam pembelajaran bahasa Indonesia; (3) tinjauan aksiologi penilaian autentik guru bahasa Indonesia dalam pembelajaran bahasa Indonesia. Penelitian ini merupakan jenis penelitian analisis konten dengan objek hasil penelitian penilaian autentik guru bahasa Indonesia dalam pembelajaran bahasa Indonesia. Teknik analisis data yang digunakan dalam penelitian ini adalah penafsiran secara deskriptif. Dari hasil analisis yang dilakukan dapat disimpulkan bahwa (1) penilaian autentik dalam pembelajaran bahasa Indonesia didapat dari nilai atau skor yang diperoleh dari kemampuan peserta didik ketika proses belajar mengajar. Keterampilan pembelajaran peserta didik lebih ditekankan pada teks; (2) metode yang dapat digunakan untuk melaksanakan penilaian autentik; dan (3) nilai etika seseorang dalam melakukan pengambilan skor.
\end{abstract}

Kata kunci: Penilaian autentik, ontologi, epistimologi, aksiologi

\section{A. PENDAhULUAN}

Pembelajaran terdiri dari tiga tahap utama yaitu perencanaan, pelaksanaan pembelajaran serta evaluasi. Penilaian sebagai bagian dalam proses pembelajaran yang terletak pada tahap evaluasi. Penilaian dalam pembelajaran dilakukan untuk mengukur ketercapaian dari tujuan pembelajaran. Penilaian yang hanya difokuskan pada ranah kognitif saja kurang memuaskan dan kurang menggambarkan adanya hasil belajar peserta didik, sehingga tidak dapat memberikan gambaran perkembangan pengalaman belajar peserta didik. Gambaran perkembangan pengalaman belajar seperti ini perlu diketahui guru setiap saat agar dapat memastikan benar tidaknya proses belajar yang telah dilakukan. Dengan demikian, penilaian autentik diarahkan pada proses mengamati, menganalisis, dan menafsirkan data yang telah terkumpul ketika atau pada saat proses pembelajaran berlangsung, bukan sematamata hanya pada hasil pembelajaran saja.

Sa'ud (2008: 172) mengemukakan bahwa asesmen merupakan proses pengumpulan data hasil yang bisa memberikan gambaran perkembangan belajar peserta didik. Penilaian dilakukan untuk melihat apakah pembelajaran berjalan dengan baik dan apakah peserta didik dapat belajar dengan baik. Untuk mendapatkan informasi dari hasil belajar secara menyeluruh 
perlu dilakukan penilaian autentik. Penilaian autentik dilaksanakan secara mendalam dan terintegrasi dalam proses pembelajaran.

Perencanaan penelitian autentik ini dapat ditempuh dengan pengembangan penilitian autentik. Muller dalam Nurgiyantoro (2013: 310) mengemukakan bahwa ada beberapa langkah yang perlu ditempuh dalam pengembangan penilaian autentik, yaitu penentuan standar, penentuan tugas autentik, pembuatan kriteria, dan pembuatan rubrik. Pengembangan dari penilaian autentik ini menjadi standar awal pada tahap perencanaan penilaian autentik.

Kunandar (2011: 401-427) mengemukakan ada tujuh teknik yang dapat digunakan untuk mengumpulkan informasi perkembangan belajar peserta didik, yaitu penilaian unjuk kerja, penilaian sikap, penilaian tertulis, penilaian proyek, penilaian produk, penilaian portofolio, dan penilaian diri. Garis besar dari penilaian otentik yaitu penilaian unjuk kerja, penilaian sikap, penilaian tertulis, penilaian proyek, pertanyaan terbuka, dan penilaian yang dilakukan oleh sejawat.

Dalam pembelajaran bahasa Indonesia, yang dinilai merupakan keterampilan berbahasa peserta didik. Keterampilan tersebut meliputi menyimak, berbicara, membaca, dan menulis. Keterampilan menulis dirasa sebagai kegiatan yang kompleks karena untuk dapat menulis, perlu penguasaan mengenai topik yang ditulis dan penguasaan bahasa. Kartono (2009: 17) mengemukakan bahwa menulis merupakan aktivitas yang kompleks, bukan hanya sekedar mengguratkan sebuah kalimat melainkan lebih dari itu. Akan tetapi, di balik kerumitan menulis memiliki manfaat yang besar dalam mengembangkan daya inisiatif dan kreativitas, kemampuan menemukan, mengumpulkan, serta mengolah informasi. Dengan begitu, pembelajaran menulis sangat penting untuk meningkatkan kemampuan menulis peserta didik.

Kurikulum 2013 menitikberatkan pada kompetensi pengetahuan, sikap, dan keterampilan. Ketiga komponen tersebut secara eksplisit dinyatakan dalam kompetensi inti yang harus dimiliki oleh peserta didik. Kurikulum 2013 juga mengatur kegiatan pembelajaran peserta didik yang mengutamakan pendekatan ilmiah (scientific) yaitu, mengamati, menanya, menalar, mencoba, dan mengomunikasikan. Perubahan yang mendasar juga berdampak pada sistem penilaian yang lebih mengarah ke penilaian autentik. Penilaian autentik ini memiliki relevansi yang kuat terhadap pendekatan scientific dalam pembelajaran sesuai dengan tuntutan dari kurikulum 2013. Penilaian autentik dapat menggambarkan peningkatan hasil belajar peserta didik baik dalam rangka mengamati, menanya, menalar, mencoba, dan 
mengomunikasikan. Kurikulum juga mengarahkan agar hasil dari belajar peserta didik dikumpulkan melalui hasil kerja peserta didik (portofolio), hasil karya (produk), penugasan, kinerja (performance), serta tes tertulis (paper and pen). Cara tersebut lebih autentik dan lebih representatif untuk mengukur serta menilai keterampilan berbahasa peserta didik.

Pada penilaian autentik menjadi lebih rumit, karena harus dirancang dengan baik dari segi teknik dan bentuk yang kompleks dibandingkan dengan penilaian pada KTSP. Penilaian pembelajaran menjadi lebih kompleks karena harus memenuhi kriteria autentik yang mampu menggambarkan proses serta hasil belajar peserta didik yang mengacu pada aspek pengetahuan, sikap, dan keterampilan dengan teks sebagai basis dari pembelajaran. Masih banyak kendala yang dialami oleh guru dari masa transisi KTSP ke Kurikulum 2013 yaitu dari penilaian autentik.

Untuk itu perlu banyak kajian dan penelitian yang terkait dengan proses penilaian autentik dalam pelajaran bahasa dan sastra Indonesia di sekolah agar kualitas produk penilaian yang dihasilkan oleh guru semakin berkualitas baik dan sesuai yang diharapkan oleh Kurikulum 2013. Maka dari itu, dalam artikel ini akan membahas tentang landasan ontologis, epistemologis, dan aksiologis penilaian autentik. Landasan ontologis dalam hal ini berkaitan dengan objek yang akan dikaji yaitu penilaian autentik dalam pembelajaran bahasa dan sastra Indonesia, kemudian epistemologi berkaitan dengan teori dan metode dari penilaian autentik, sedangkan aksiologis berkaitan dengan manfaat penilaian autentik dalam pembelajaran bahasa dan sastra Indonesia.

Landasan ontologis, epistemologi, dan aksiologis penilaian autentik dalam pembelajaran bahasa dan sastra Indonesia harus dikaji karena cara pemerolehan ilmu perlu diuji kebenarannya, haruslah bersifat ilmiah, logis, sistematis, dan empiris. Karena penilaian autentik merupakan sebuah ilmu maka harus melalui tiga landasan yaitu landasan ontologis, epistemologis, dan aksiologis.

Berdasarkan uraian di atas, dapat dirumuskan permasalahan dalam penelitian ini, yaitu: (1) bagaimana tinjauan ontologi penilaian autentik guru bahasa Indonesia dalam pembelajaran bahasa Indonesia?; (2) bagaimana tinjauan epistimologi penilaian autentik guru bahasa Indonesia dalam pembelajaran bahasa Indonesia?; dan (3) bagaimana tinjauan aksiologi penilaian autentik guru bahasa Indonesia dalam pembelajaran bahasa Indonesia?

Terdapat beberapa penelitian yang telah dilakukan terkait dengan tinjauan ontologi, epistimologi, dan aksiologi. Penelitian tersebut berjudul "Tinjauan Filsafati (Ontologi, 
Epistimologi dan Aksiologi) Manajemen Pembelajaran Berbasis Teori Sibernetik" yang ditulis oleh Tri Suminar. Dari hasil analisis penelitian ini diperoleh data kesimpulan tinjauan aspek secara ontologis yang menjelaskan mengenai daya ingat individu terdiri dari struktur informasi yang terorganisasi dan proses penelusuran bergerak secara hirarkis dari informasi yang paling umum dan inklusif ke informasi yang paling rinci sampai informasi yang diinginkan diperoleh. Hasil analisis dari tinjauan epistemologi menjelaskan bahwa cara belajar yang ditentukan oleh sistem informasi. Komponen pemrosesan informasi berdasarkan perbedaan fungsi, kapasitas, bentuk informasi dan proses terjadinya lupa yang dijelaskan melalui 3 komponen: Sensory memory atau sensory register, Short Term Memory, Long Term Memory. Kemudian tinjauan dari aspek aksiologi dijelaskan bahwa pengelolaan pembelajaran menuntut pembelajaran untuk diorganisir dengan baik yang memerhatikan kondisi internal serta eksternal, karena memori manusia mempunyai kapasitas yang terbatas.

\section{B. KAJIAN TEORI}

\section{Penilaian Autentik}

Kurikulum 2013 menekankan pentingnya penilaian autentik. Penilaian autentik merupakan bentuk penilaian untuk memenuhi standar penilaian sekaligus sebagai karakteristik penilaian yang ideal dalam implementasi kurikulum 2013.

Calison dalam Nurgiyantoro (2013: 305) mengemukakan bahwa penilaian autentik merupakan sebuah penilaian proses yang di dalamnya melibatkan berbagai kinerja yang mencerminkan bagaimana peserta didik belajar, mencapai hasil, mencapai motivasi dan sikap yang terkait dengan proses pembelajaran. Penilaian autentik dapat dimaknai sebagai penilaian yang bertolak dari proses yang nyata dalam belajar dan hasil yang dicapai dari kegiatan tersebut.

Dalam penilaian autentik, penilaian proses dan hasil menjadi dua hal yang penting. Proses dan hasil merupakan tampilan peserta didik dalam rangkaian kegiatan pembelajaran yang dapat dinilai secara objektif apa adanya dan tidak hanya berdasarkan hasil dari produk akhir semata.

\section{Penilaian Autentik dalam Mata Pelajaran Bahasa Indonesia}

Ada berbagai jenis penilaian autentik yang meliputi wawancara, menceritakan kembali isi teks atau cerita, karya tulis, tugas proyek, eksperimen, eksibisi, pertanyaan terbuka dan menjawab soal dengan uraian, portofolio, dan pengamatan yang dilakukan oleh 
guru (Nurgiyantoro, 2011: 34). Bentuk penilaian tersebut yang dapat diterapkan dalam pembelajaran bahasa adalah penilaian kinerja, wawancara lisan, pertanyaan terbuka, menceritakan kembali isi teks atau cerita, proyek, dan portofolio.

\section{Ontologi}

Istilah "ontologi" berasal dari kata Yunani "onta" yang berarti sesuatu "yang sungguh-sungguh ada", "kenyataan yang sesungguhnya", dan "logos" yang berarti "studi tentang", "studi yang membahas sesuatu" (Angeles dalam Ihsan, 2015: 223).

Ontologi merupakan studi yang membahas tentang sesuatu yang ada. Secara sungguhsungguh ontologi juga diartikan sebagai metafisika umum yaitu cabang ilmu filsafat yang mempelajari sifat dasar dari kenyataan yang terdalam. Ontologi membahas asas-asas rasional dari kenyataan (Kattsoff dalam Ihsan, 2015: 223), sedangkan Mudhofir dalam Ihsan (2015: 224) mengemukakan bahwa ontologi sebagai suatu usaha intelektual untuk mendeskripsikan sifat-sifat umum dari kenyataan, suatu usaha untuk memperoleh penjelasan yang benar tentang kenyataan, sifat pokok kenyataan dalam aspeknya yang paling umum sejauh hal itu dapat dicapai, dan teori tentang sifat pokok dan struktur dari kenyataan.

Ihsan (2015: 223) mengemukakan bahwa terdapat dua objek ontologis, yaitu objek material ontologi dan objek formal ontologi. Objek material ontologi merupakan yang ada, artinya segala-galanya, meliputi wujud kongkret dan abstrak, indrawi maupun tidak inderawi. Berbeda dengan objek formal ontologi adalah memberikan dasar yang paling umum dari setiap masalah yang menyangkut manusia, dunia, dan Tuhan. Oleh karena itu, ada objek material di belakang setiap sensasi inderawi, maka demikian pula ada kenyataan metafisik di belakang segala sesuatu yang menjadi nyata dalam pengalaman hidup manusia (Kneller dalam Rukiyati \& Darmiyati Zuchdi, 2016: 33).

\section{Epistimologi}

Rukiyati dan Darmiyati Zuchdi (2016: 35) mengemukakan bahwa epistimologi dalam kaitan ilmu diartikan sebagai dasar filsafat yang menentukan arah metodologi penemuan ilmiah. Dasar epistemologi memberikan asumsi-asumsi dasar dalam memandang pengetahuan dan cara memperolehnya.

Suriasumantri (2009:105) epistemologi atau di sebut dengan metode ilmiah adalah cara yang dilakukan ilmu dalam menyusun pengetahuan yang benar. Epitemologi berupaya mencari kebenaran (truth) berdasar fakta. Kebenaran di bangun dengan logika dan di dahului 
oleh uji konfirmasi tentang data yang di himpun. Epistemologi berupaya menghimpun empiris yang relevan untuk di bangun secara rasional menjadi kebenaran ilmu.Jadi, epistimologi merupakan cara memperoleh suatu ilmu yang benar, pemerolehan ilmu pengetahuan didapat dari metode-metode yang dapat digunakan untuk menggali kebenaran dari sebuah ilmu pengetahuan.

\section{Aksiologi}

Aksiologi diartikan sebagai teori nilai yang berkaitan dengan kegunaan dari pengetahuan yang diperoleh (Suriasumantri, 2009: 234).Aksiologi merupakan cabang filsafat yang membahas teori-teori nilai dan berusaha mendeskripsikan mengenai kebaikan dan perilaku yang baik (Gutek dalam Rukiyati dan Darmiyati Zuchdi, 2016: 15). Secara tidak langsung, landasan aksiologis ilmu tercermin di dalam tujuan dan metode penelitian ilmiah. Tujuan penelitian ilmiah hendaknya didasarkan oleh nilai-nilai yang diyakini yang berusaha untuk diwujudkan dalam tindakan nyata (Rukiyati dan Darmiyati Zuchdi, 2016: 36).

Suriasumantri (2009: 234) mengatakan aksiologi sebagai teori nilai yang berkaitan dengan kegunaan dari pengetahuan yang diperoleh, untuk dipergunakan dalam berbagai aktivitas yang memiliki manfaat atau kegunaan sebagai implementasi dan peran pengetahuan tersebut. Dengan kata lain aksiologi dianggap sebagai cabang filsafat yang mempelajari tentang nilai secara umum. Pada hal ini, ilmu digunakan sebagai cara atau alat dalam meningkatkan taraf hidup manusia dengan memperhatikan kodrat manusia, martabat manusia, dan kelestarian atau keseimbangan alam. Jadi, aksiologi berkenaan dengan manfaat dari suatu ilmu pengetahuan untuk dipergunakan dalam berbagai aktivitas yang memiliki manfaat kegunaan sebagai implementasi dan peran pengetahuan tersebut. Manfaat ada dua macam yaitu etika dan estetika, etika adalah nilai atau manfaat dari sebuah ilmu berwujud moral dan tingkah laku setelah seseorang mendapatkan ilmu tersebut, sedangkan estetika adalah keindahan atau berkaitan dengan rasa keindahan, ketentraman dan kenyamanan akibat yang timbul dari ilmu yang kita pelajari.

\section{METODE PENELITIAN}

Penelitian ini merupakan jenis penelitian analisis konten inferensial dengan objek hasil penelitian penilaian autentik guru bahasa Indonesia. Validitas data menggunakan validitas semantis dan reliabilitas data menggunakan intrareter. Teknik analisis data yang digunakan dalam penelitian ini menggunakan rancangan penelitian deskriptif kualitatif. 
Subjek dalam penelitian ini adalah guru bahasa Indonesia. Hal ini sesuai dengan pandangan yang mengatakan bahwa subjek penelitian merupakan benda, hal atau orang tempat melekat dan yang dipermasalahkan dalam penelitian (Suandi, 2008: 31). Objek dari penelitian ini adalah teknik penilaian autentik guru bahasa Indonesia dalam pembelajaran bahasa Indonesia.

Teknik pengumpulan data menggunakan metode observasi, wawancara, serta dokumentasi. Instrumen dalam penelitian ini merupakan lembar observasi, pedoman wawancara serta dokumen berupa Rancangan Pelaksanaan Pembelajaran yang telah dibuat oleh guru bahasa Indonesia, hasil kerja peserta didik, dan foto. Metode observasi yang digunakan oleh peneliti untuk mencari data mengenai pelaksanaan penilaian autentik yang dilakukan oleh guru bahasa Indonesia dan dari observasi juga akan terlihat sekiranya kendalakendala yang dialami oleh guru ketika melaksanakan penilaian autentik.

Metode observasi yang digunakan adalah teknik observasi nonpartisipatif. Peneliti tidak ikut serta dalam kegiatan hanya berperan mengamati kegiatan berlangsung (Sukmadinata, 2009: 220). Peneliti berada di dalam kelas untuk mengadakan pengamatan dan pencatatan langsung terhadap proses pelaksanaan pembelajaran sampai pada melakukan evaluasi atau penilaian, tetapi peneliti tidak terlibat langsung dalam aktivitas yang dilakukan subjek penelitian.

Metode pengumpulan data dengan wawancara dilakukan dengan mengajukan pertanyaan kepada responden. Hal ini sejalan dengan pendapat Sugiyono (2007: 194) yang mengemukakan bahwa wawancara digunakan untuk mengetahui hal-hal mendalam dari responden. Wawancara merupakan suatu bentuk komunikasi verbal atau semacam percakapan yang bertujuan memperoleh informasi (Suandi, 2008: 44). Dalam penelitian ini, wawancara yang dilakukan merupakan wawancara yang tidak terstruktur agar responden bisa menjawab secara bebas sesuai dengan pikiran da nisi hatinya. Responden secara spontan dan lugas dapat mengemukakan segala sesuatu yang ingin dikemukakannya. Metode wawancara dalam penelitian ini bertujuan untuk mengklarifikasi dan melengkapi data yang telah diperoleh dalam observasi. Dengan demikian, peneliti bisa memperoleh gambaran yang luas mengenai kendala-kendala yang dihadapi oleh guru bahasa Indonesia saat melakukan penilaian autentik. Instrumen pada metode ini menggunakan pedoman wawancara.

Metode dokumentasi digunakan untuk memperoleh data yang bersumber pada tulisan, seperti buku, dokumen, peraturan-peraturan, dan sebagainya (Arikunto, 2005: 158). 
Pernyataan tersebut didukung oleh Iskandar (2009: 73) yang menyatakan bahwa suatu metode dokumentasi sering dikenal dengan metode pengumpulan dokumentasi yang merupakan penelaah terhadap referensi yang berhubungan dengan focus permasalahan peneliti. Dalam penelitian ini, metode dokumentasi yang digunakan untuk memperoleh data yang benar-benar valid dan memang diperlukan dalam penelitian. Peneliti akan mengumpulkan data berupa tulisan peserta didik yang sudah dikoreksi oleh guru seperti portofolio dan RPP yang berisikan rubrik penilaian peserta didik. Dengan demikian, peneliti akan mengetahui pelaksanaan penilaian autentik guru bahasa Indonesia saat pembelajaran.

Metode analisis data dalam penelitian harus disesuaikan dengan jenis data yang sudah dikumpulkan. Teknik analisis data yang dilakukan bersamaan dengan pengumpulan data (Sugiyono, 2007: 401). Dalam penelitian ini peneliti menggunakan metode deskriptif kualitatif sebagai metode analisis data. Analisis data menggunakan menggunakan deskriptif kualitatif dilakukan dengan memberikan predikat kepada variabel yang diteliti sesuai dengan kondisi sebenarnya (Arikunto, 2005: 269). Berdasarkan metode tersebut, peneliti dapat menggunakan teori-teori yang relevan dan telah dipaparkan dalam landasan teori sebagai acuan bagi peneliti untuk mendalami objek penelitian. Menurut (Miles dan Huberman dalam Sugiyono, 2007:337), aktivitas dalam analisis data kualitatif dilakukan dengan interaktif dan berlangsung secara terus menerus sampai tuntas. Analisis data deskriptif kualitatif diarahkan pada identifikasi dan klasifikasi untuk mendapatkan deskripsi yang jelas, rinci, memadai, dan berkenaan dengan penggunaan teknik penilaian autentik guru bahasa Indonesia.

Pengambilan simpulan yaitu peneliti merumuskan simpulan berdasarkan data yang sudah diperoleh dan menyajikan secara deskriptif kualitatif yaitu menyajikan temuan di lapangan menggunakan kata-kata. Penarikan simpulan disesuaikan dengan temuan di lapangan yang disajikan dalam penyajian data dan berkaitan pula dengan rumusan masalah.

\section{HASIL DAN PEMBAHASAN}

Hasil dari penelitian mencakup pelaksanaan penilaian autentik guru bahasa Indonesia. Pentingnya penilaian dalam kegiatan pembelajaran menjadi hal yang tidak terbantahkan. Penilaian merupakan suatu hal yang tidak bisa lepas dari kegiatan pembelajaran. Dengan kata lain, penilaian merupakan salah satu kegiatan yang harus dilakukan oleh guru dan peserta didik dari serangkaian kegiatan belajar mengajar yang mereka lakukan. Sebagai pihak yang bertanggungjawab atas keberhasilan kegiatan pembelajaran di kelas, guru dituntut untuk mampu mempersiapkan dan melakukan penilaian dengan baik sehingga tujuan pembelajaran 
yang telah dicapai dapat maksimal. Penilaian yang baik harusnya dilakukan dengan cara berkesinambungan.

\section{Ontologis}

Ontologis merupakan objek kajian dalam suatu ilmu,(Mudhofir dalam Ihsan, 2015: 224) mengemukakan bahwa ontologi merupakan suatu usaha intelektual untuk mendeskripsikan sifat-sifat umum dari kenyataan, suatu usaha untuk memperoleh penjelasan yang benar tentang suatu kenyataan, studi tentang sifat pokok kenyataan dalam aspeknya yang paling umum sejauh hal itu dapat dicapai, teori tentang sifat pokok dan struktur dari kenyataan.

Ihsan (2015: 223) menjelaskan bahwa ada dua objek ontologis, yaitu objek material ontologi dan objek formal ontologi. Objek material ontologi merupakan yang ada, artinya segala-galanya yang meliputi ada sebagai wujud kongkret dan abstrak, indrawi maupun tidak inderawi, sedangkan objek formal ontologi merupakan dasar yang paling umum tiap masalah yang menyangkut manusia, dunia, dan Tuhan. Titik tolak dan dasar ontologi memberikan dasar yang paling dekat dengan manusia sendiri dan dunianya. Oleh karena itu ada objek material di belakang setiap sensasi inderawi, maka ada kenyataan metafisik di belakang segala sesuatu, yang menjadi nyata dalam pengalaman hidup manusia (Kneller dalam Rukiyati dan Darmiyati Zuchdi, 2016: 33).

Berdasarkan penjelasan di atas dapat berarti yang menjadi objek ontologis dalam penilaian autentik dari mata pelajaran bahasa Indonesia adalah nilai atau skor yang diperoleh dari keterampilan peserta didik ketika proses belajar mengajar di dalam kelas. Keterampilan tersebut lebih ditekankan pada kemampuan menulis karena di dalam kurikulum 2013 lebih menekankan pada pembelajaran yang berbasis dengan teks. Selain itu, sikap juga menjadi salah satu objek yang diamati dalam penilaian autentik ini sesuai dengan kompetensi inti yang ada pada kurikulum 2013. Untuk mendapatkan skor tersebut, guru harus membuat angket sikap dan pengamatan terhadap sikap peserta didik di kelas terutama untuk sikap religius.

\section{Epistimologis}

Landasan epistimologi penilaian autentik mata pelajaran Bahasa Indonesia adalah berkenaan dengan pemerolehan ilmu penilaian autentik yang digunakan dalam pelajaran bahasa Indonesia. Terdapat beragam teori yang mendukung tentang penilaian autentik, 
menjelaskan bagaimana hakikat penilaian autentik, menjelaskan tentang proses penilaian autentik dan cara untuk mendapatkan nilai secara autentik.

Penilaian autentik berdasarkan penjelasan sebelumnya harus sudah di kuasai oleh guru. Untuk itu guru harus mampu berupaya untuk mewujudkan penilaian autentik seperti yang diharapkan oleh kurikulum 2013. Mueller mengemukakan bahwa terdapat sejumlah langkah yang perlu ditempuh dalam mengembangkan penilaian autentik, yaitu penentuan standar, penentuan tugas autentik, pembuatan kriteria, dan pembuatan rubrik (Nurgiyantoro, 2011: 33).

Selanjutnya ada beberapa metode yang dapat digunakan untuk melaksanakan penilaian autentik seperti yang sudah dikemukakan, ada berbagai jenis penilaian autentik yang meliputi wawancara, menceritakan kembali isi teks atau cerita, karya tulis, tugas proyek, eksperimen, pertanyaan terbuka dan menjawab soal dengan uraian, portofolio, dan pengamatan oleh guru (Nurgiyantoro, 2011: 34). Di antara bentuk penilaian ini, penilaian yang dapat diterapkan dalam pembelajaran bahasa adalah penilaian kinerja, wawancara lisan, pertanyaan terbuka, menceritakan kembali isi teks atau narasi, proyek, dan portofolio (Nurgiyantoro, 2011: 34-37).

\section{Aksiologi}

Landasan aksiologi penilaian autentik merupakan nilai-nilai yang bermanfaat dan penilaian autentik dari penilaian autentik mata pelajaran bahasa dan sastra Indonesia. Berkenaan dengan hal tersebut penilaian autentik perlu dikembangkan agar sesuai dengan kaidah-kaidah penilaian autentik. Berkenaan dengan aksiologi penilaian autentik juga menekankan pada nilai etika dan estetika. Estetika yang dimaksud merupakan cara atau proses dari pengambilan nilai peserta didik. Seorang guru tentunya dalam melakukan pengambilan nilai dan memberi nilai kepada peserta didik tentunya harus objektif dan sesuai dengan keadaan yang sesungguhnya di lapangan.

Pada hakikatnya penilaian autentik merupakan penilaian yang bertujuan untuk menggambarkan kemampuan peserta didikterhadap cara mereka dalam mengahadapi sebuah permasalahan. Penilaian pendidikan merupakan pengumpulan dan pengolahan informasi untuk mengukur pencapaian hasil belajar dari peserta didik yang mencakup; (1) penilaian autentik; (2) penilaian diri; (3) penilaian berbasis portofolio; (4) ulangan harian; (5) ulangan tengah semester; (6) ulangan akhir semester; (7) ujian tingkat kompetensi; (8) ujian mutu tingkat kompetensi; (9) ujian sekolah; dan (10) ujian nasional (Permendikbud No 66 Tahun 
2013). Mueller dalam Nurgiyantoro dan Pujiati (2010: 9) mengemukakan bahwa penilaian autentik merupakan suatu bentuk tugas yang menghendaki pembelajar untuk menunjukkan kinerja di dunia nyata secara bermakna yang merupakan esensi pengetahuan dan keterampilan. Penilaian autentik merupakan penilaian kinerja atau performasi yang meminta guru untuk mendemonstrasikan keterampilan dan kompetensi tertentu dari penerapan pengetahuan yang dikuasainya.

\section{E. KESIMPULAN}

Dari hasil analisis di atas, dapat ditarik kesimpulan bahwa secara ontologis penilaian autentik dalam pembelajaran bahasa Indonesia didapat dari nilai atau skor yang diperoleh dari kemampuan peserta didik ketika proses belajar mengajar. Keterampilan pembelajaran peserta didik lebih ditekankan pada teks. Untuk mendapatkan skor tersebut, guru harus membuat angket atau penilaian sikap dan pengamatan terhadap sikap peserta didik di dalam kelas. Selanjutnya dari aspek epistimologi penilaian autentik dalam pembelajaran bahasa Indonesia ada beberapa metode yang dapat digunakan untuk melaksanakan penilaian autentik. Jenis metode penilaian tersebut, antara lain: wawancara, menceritakan kembali isi teks atau cerita, karya tulis, tugas proyek, eksperimen, pertanyaan terbuka, portofolio, dan pengamatan yang dilakukan oleh guru. Dari segi aksiologi penilaian autentik dalam pembelajaran bahasa Indonesia nilai-nilai manfaat dari penilaian autentik terkait dengan nilai etika seseorang yang sudah mempelajari penilaian autentik tentunya dalam melakukan pengambilan skor pasti bersifat objektif sesuai dengan kondisi peserta didik di lapangan dengan menggunakan alat evaluasi yang sesuai dengan penilaian autentik, seperti penilaian kinerja, wawancara secara lisan, pertanyaan terbuka, proyek, dan portofolio.

\section{F. SARAN}

Berdasarkan kesimpulan yang diperoleh dalam penelitian ini maka peneliti memberi saran antara lain: penilaian autentik guru dalam pelaksanaannya belum benar-benar menggunakan instrumen secara maksimal dalam melaksanakan penilaian autentik bahasa Indonesia untuk memperoleh penilaian yang objektif. Guru perlu menambah pengetahuan serta referensi secara mandiri dengan mencari bagaimana penilaian dari hasil belajar kurikulum 2013 dari sumber tertentu. Guru juga perlu mengikuti pelatihan-pelatihan mengenai kurikulum 2013 khususnya merdeka belajar yang diadakan dan disosialisasikan oleh pemerintah khususnya pada standar penilaian hasil belajar siswa dalam kurikulum 2013. 


\section{DAFTAR PUSTAKA}

Arikunto, Suharsimi. 2005. Manajemen Pendidikan. Jakarta: Rineka Cipta.

Ihsan, A. Fuad. 2015. Filsafat Ilmu. Jakarta: Rineka Cipta.

Iskandar. 2009. Metodologi Penelitian Kualitatif. Jakarta: Gaung Persada.

Kartono. 2009. Menulis Tanpa Rasa Takut Membaca Realitas dengan Kritis. Yogyakarta: Kanisius.

Kunandar. 2011. Guru Profesional Implementasi Kurikulum KTSP dan Sukses Sertifikasi Guru. Jakarta: PT Raja Grafindo Persada.

Nurgiyantoro, Burhan. 2011. Penilaian Otentik. Yogyakarta: Gajah Mada University Press.

Nurgiyantoro, Burhan. 2013. Penilaian Pembelajaran Bahasa. Yogyakarta: BPFE Yogyakarta.

Nurgiyantoro, Burhan dan Pujiati Suyata. 2010. Model Penilaian Otentik dalam Pembelajaran Bahasa. Yogyakarta: UNY Press

Permendikbud Nomor 66 Tahun 2013 tentang Standar Penilaian Pendidikan.

Rukiyanti dan Darmiyati Zuchdi. 2016. Filsafat Ilmu. Yogyakarta: Universitas Negeri Yogyakarta.

Sa'ud. Udin Syaefudin. 2008. Inovasi Pendidikan. Bandung: Alfabeta.

Suandi, I Nengah. 2008. Buku Ajar Penelitian Bahasa dan Sastra Indonesia. Singaraja: Undiksha.

Sugiyono. 2007. Metode Penelitian Pendidikan (Pendekatan Kuantitatif, Kualitatif, dan $R \& D)$. Bandung: Alfabeta.

Sukmadinata, Nana Syaodih. 2009. Metode Penelitian Pendidikan. Bandung: PT Remaja.

Suriasumantri, Jujun S. 2009. Filsafat Ilmu: Sebuah Pengantar Populer. Jakarta: Pustaka Sinar Harapan.

Tri Suminar. 2016. Tinjauan Filsafati (Ontologi, Epistemologi Dan Aksiologi) Manajemen Pembelajaran Berbasis Teori Sibernetik. Jurnal Edukasi. Vol 1, no 2. 